\title{
ROLE OF AUTHENTIC VIDEOS AND TELECINEMATIC DISCOURSE ANALYSIS IN TEACHING TECHNICAL STUDENTS ENGLISH FOR SPECIFIC PURPOSES
}

\section{Shevchenko Mariana ${ }^{1}$}

DOI: https://doi.org/10.30525/978-9934-571-89-3_34

In the present constantly-developing world, innovative technologies are becoming a primary object of study and improvement. They are created by students of technical specialties. In addition to general English, technical students of non-English speaking countries are usually taught English for Specific Purposes at universities. This type of the English language, being a branch of EFL (English as a Foreign Language), has the aim of providing future professionals in a specific field of study, for instance engineering, with the knowledge of a foreign language corresponding to their needs and requirements in the specialty sphere $[3 ; 5]$. The primary focus is on the development of ESP students' English communication skills.

The best way to teach the students in question the English language they need is to use authentic video records in English, originally created for native speakers and not purposefully adapted for teaching ESL or EFL. Among them, the most beneficial are films, TV series, and programmes. The reason for their implementation in ESP lessons is that they are thematically-diverse, informative, attention-grabbing, interesting, modern, and motivating. Movies and television series are popular cultural products that attract massive audiences around the world. The main advantages of such aids use - both for English lecturers and their students - are:

\footnotetext{
${ }^{1}$ National Technical University of Ukraine

"Igor Sikorsky Kyiv Polytechnic Institute", Ukraine
} 
- Constant relevance: their topics (events) and characters reflect aspects of the target language culture, including social realities and moral issues [Quaglio (2009), p. 17 as cited in 1, p. 181-182].

- Accessibility: nowadays, they can be easily found on YouTube or on the websites of such OTT (over-the-top) media services providers like Netflix, Hulu, Amazon Video, and many others in various countries worldwide, as well as be used in- and outside the class. Thereby, it has become obvious in recent years that the Internet has contributed to the revolution in English language teaching, providing real-time access to authentic materials everywhere.

Authentic multimedia aids, being bearers of the 'real' English language, are beneficial for teaching students of any specialty the English language, both general and for specific purposes, in its natural form, i.e. in the way it is used by native speakers, - with authentic vocabulary, including neologisms and idioms, and grammar forms. Hence, the authentic language used in movies, TV series, and programmes can become an effective language and communication model for students.

It may seem complicated for some English lecturers to prepare ESP lessons with tasks based on authentic videos viewing, but with proper preparation, it should not be that hard and may become even fascinating for the educator. It is better to start the development of foreign language lessons using videos with the telecinematic discourse (TD) analysis [7] of clips the lecturer would like to employ. The TD analysis prior to the English teaching process at university creates an interdisciplinary study between applied- and stylistic linguistics, pragmatics, and pedagogy (education). It is done to analyse the types of spoken language, lexical and grammar features, as well as the dependence of context on the meaning of spoken phrases that the ESP students will encounter during the viewing.

Although films and TV series are somewhat different in terms of the duration of the complete story presentation and the characters development, they have enough similarities to be analysed and used to the same extent in ESP lessons. Due to these similarities, Piazza, Bednarek, and Rossi [7, p. 1] have coined the term "telecinematic discourse" to refer to the language of TV and cinema together.

The telecinematic discourse comprises both television and cinema dialogues. The former is the dialogue uttered by actors on screen as their characters in TV series, while the latter is their talk in movies. The following similarities between television and movie narratives are the justification of them being examined together during the analysis [2]: 1) both are multimodal audiovisual texts, comprising language and kinesics, 2) both are fictional narratives, with plot and characters, 3) both are representations/recreations of the 'real' world, 4) both show a 'double' communicative interaction plane: interaction between the on-screen characters within the narrative, and interaction between the characters and the external audience of the narrative; 5) dialogues of both are scripted and multi-functional (e.g. defining genres, contributing to characterisation, engaging the audience etc.).

Both media products - films and series - produce texts with clear boundaries within which the diverse elements of image and sound 'cohere' on screen [Bell 
(2008), p. 15 as cited in 7]. These texts in the written form are called scripts and are the key elements of the telecinematic discourse analysis alongside the features of the heard oral speech.

In the process of discourse analysis either audio and/or video recording of interaction or the collected together textual documents may be studied [8]. In terms of the telecinematic discourse analysis, both aspects can be scrutinized. Most importantly for qualitative analysis, the authentic videos to be used in the ESP lessons should be related to the students' specialty in some aspect.

In order to conduct telecinematic discourse analysis, all the selected texts (movie/series/programmes scripts or transcripts) should be analysed in the context of textual analysis. This is due to the fact that it is the method researchers use to describe and interpret the features of a recorded or visual message, describing the content, structure, and functions of the messages contained in texts [4]. The text linguistics sets out the following criteria:

- Text type. This notion, cohesion, and coherence are interrelated. Most linguists agree on the classification into 5 text types [6, p. 149]: narrative, descriptive, argumentative, instructive, and comparison/contrast. Sometimes text types may be divided according to 1) their function, 2) the topic, the producer and the addressee, or 3 ) the style. However, various text types frequently overlap, and often the text cannot be identified as just one text type.

- Structure: cohesion (syntax) and coherence (semantics). The former is, basically, conventions of the text (spelling, punctuation, capitalization, grammar, and sentence structure), whereas the latter is lexis, i.e. concepts and relations, and the way it is linked, relevant and used in the text to achieve effective communication.

- Meaning and Context.

In addition to the above-mentioned textual analysis criteria, interaction analysis should be also applied to oral speech heard in the viewed video record [4]: linguistic features (words and sentence components, nonverbal features, i.e. kinesics, interpretive aspects of language) and types of topics.

The result of the ESP lecturer's telecinematic discourse analysis will present concordances that will become, in their turn, the basis for vocabulary exercises in the ESP lessons with authentic videos, including film clips. An English lecturer can determine the concordances in their selected authentic video records (fragments of movies, series, and programmes) using corpus linguistic software, for example, WordSmith, which helps to find in the text all instances of a word or phrase (concords), salient words in a text or set of texts, or wordlists in the text(s) in alphabetical and frequency order.

To sum up, authentic videos are the most productive English-teaching aids in English for Specific Purposes lessons, specifically in teaching technical students listening and speaking, if used wisely - after the discourse analysis, selection of the appropriate vocabulary, and well-thought-out tasks planning. The TD analysis, in its turn, plays an essential role in the selection of suitable vocabulary and other common features (grammar, linking words, etc.) for the ESP students' use in the English language practice at university and in future professional situations. 


\section{References:}

1. Bednarek, M. (2010). The Language of Fictional Television: Drama and Identity. London; New York: Continuum. 304.

2. Bednarek, M. (in press). The Sydney Corpus of Television Dialogue: Designing and building a corpus of dialogue from US TV series. Available: https://www.academia.edu/37736431/ Bednarek_M._in_press_The_Sydney_Corpus_of_Television_Dialogue_Designing_and_building_a_ corpus_of_dialogue_from_US_TV_series. Last accessed $5^{\text {th }}$ April 2019.

3. Dudley-Evans, T., St. John, M. (1998). Developments in English for Specific Purposes: A multi-disciplinary approach. Cambridge: Cambridge University Press. 301.

4. Frey, L.R., Botan, C.H., Kreps, G.L. (1999). Investigating Communication: An Introduction to Research Methods. $2^{\text {nd }}$ ed. Boston: Allyn \& Bacon. 528.

5. Javid, C.Z. (2013). English for Specific Purposes: Its Definition, Characteristics, Scope and Purpose. European Journal of Scientific Research, 112 (1), 138-151.

6. Medina, B.L. (2002/2003). The role of text linguistics in the foreign language class. Encuentro Revista de investigación e innovación en la clase de idiomas. 13-14, 148-156.

7. Piazza, R., Bednarek, M., Rossi, F. (2011). 'Introduction: Analysing telecinematic discourse.' In: Piazza, R., Bednarek, M., Rossi, F. (eds). Telecinematic Discourse: Approaches to the Language of Films and Television Series. Amsterdam/Philadelphia: John Benjamins, 1-17.

8. Wiggins, S. (2009). Discourse Analysis. In: Encyclopedia of Human Relationships. California, USA: Sage Publications, 427-430. 